\title{
The Enhancing Effect of Plants Growth Biostimulants in Garlic Cultivation on the Chemical Composition and Level of Bioactive Compounds in the Garlic Leaves, Stems and Bulbs
}

\author{
Elżbieta JĘDRSZCZYK ${ }^{1 *}$, Aneta KOPEĆ ${ }^{2}$, Piotr BUCKI ${ }^{1}$, \\ Anna M. AMBROSZCZYK ${ }^{1}$, Barbara SKOWERA ${ }^{3}$ \\ ${ }^{1}$ University of Agriculture, Faculty of Biotechnology and Horticulture, Department of Vegetable and Medicinal Plants, al. 29 Listopada 54, 31 - \\ 425 Kraków,Poland; e.jedrszczyk@ogr.ur.krakow.pl ( ${ }^{*}$ correspondingauthor);piotr.bucki91@gmail.com;a.ambroszczyk@ur.krakow.pl \\ ${ }^{2}$ University of Agriculture, Faculty of Food Technology; Department of Human Nutrition Balicka 122 St., 30-149 Kraków, \\ Poland;a.kopec@ur.krakow.pl \\ ${ }^{3}$ University of Agriculture, Faculty of Environmental Engineering and Land Surveying, Department of Ecology, Climatology and Air Protection, \\ al. Mickiewicza 24/28,30-059Kraków, Poland; rmskower@cyf-kr.edu.pl
}

\begin{abstract}
The aim of the study was to evaluate the effect of biostimulants enhancing plant growth and development, i.e. organic stimulator based on metal sulphates, Bacillus subtilis, humic acids, on the chemical composition and level of bioactive compounds in garlic leaves, stems, and bulbs. The study was conducted in three growing seasons on the 'Ornak' winter garlic cultivar. The propagating material was treated in solutions of the biostimulants and after emergence the plants were sprayed with the products three times. The most valuable edible organ proved to be the leaves, which contained the most protein, fat, and mineral components expressed as ash, were the richest source of fibre, vitamin $\mathrm{C}$, and polyphenols, and also had the highest antioxidant activity among the organs tested. The nutritional value of the stems was comparable to that of the bulbs, and the level of polyphenols and antioxidant activity were even higher. The use of the growth and development biostimulants influenced the chemical composition of the garlic, but the effect was modified by the course of weather in different years of the research and also depended on edible organ. On average for years and organs all biostimulants increased the level of protein, minerals expressed as ash and enhanced antioxidant activity, whereas decreased the level of total carbohydrates.
\end{abstract}

Keywords: Allium sativum; Bacillus subtilis; edible organs; humic acids; nutritional value; product based on metal sulphates

\section{Introduction}

Garlic (Allium sativum L.) is not only a popular vegetable but also a valuable medicinal plant, whose global production is constantly increasing (FAO, 2014). The commonly used edible organ is the bulb, while the leaves and stems are discarded during technological processing (Kallel et al., 2014). Nevertheless, cultivation of garlic for bunching, using the young leaves of the plant, has become increasingly popular in recent years. This is an alternative broadening the available options in the fresh vegetable market, especially in the spring (March-May). In this case the edible young leaves in the early stage of growth and the undivided bulbs are used for food (Rekowska and Skupień, 2008). In Poland this type of cultivation is just beginning to gain momentum, while in many countries, especially Asian countries, with a well-established culture of eating leafy vegetables, it has been common for a number of years (Wu et al., 2016). In Central Asia, where garlic originated, all of its parts are used in folk medicine (Mikaili et al., 2013; Shah, 2014). Kamruzzaman et al. (2011) refer to the leaves and stems of garlic as green, edible material with a characteristic spicy flavour and high protein content. Many authors report that the procedure of removing stems during the growing period can cause an increase in total yield of over 30\% and an increase in the percentage of heads with a larger diameter. The effect of stem removal is largely dependent on the cultivar and on growing conditions (Rosen and Tong, 2001; Garg and Sekhon, 2016). Another significant factor is when the procedure is carried out (Pelter et al., 2005). The stems are suitable as food, as their nutritional value is comparable to that of the bulbs and their level of bioactive compounds such as polyphenols and their antioxidant activity is even 
82

higher. Information on consumption of young garlic stems can also be found in reports by González et al. (2012) and Shiga et al. (2015). The green material from garlic, i.e. the leaves and stems, can be used as animal feed (Kamruzzaman et al., 2011).

Due to its broad spectrum of activity garlic has long been used to treat numerous infections induced by pathogenic microbes and to combat various diseases of civilization, which has been confirmed by research (Bayan et al., 2014; Papu et al., 2014; Ourouadi et al., 2016).

Taking into account the considerable quantities of active compounds in all parts of the garlic plant and the growing range of uses for the young leaves and stems, it is crucial to develop effective methods of garlic cultivation which produce high yields while maintaining high biological quality. Therefore it is worth considering the use of products which enhance crops by reducing susceptibility to disease and increasing resistance to stress (González et al., 2012; Shafeek et al., 2016; Ali, 2017).

Products improving plant development include various kinds of stimulators. One of these is stimulator based on nano-concentrations of elements in the form of sulfates: $\mathrm{Fe}$, $\mathrm{Co}, \mathrm{Al}, \mathrm{Mg}, \mathrm{Mn}, \mathrm{Ni}$ and $\mathrm{Ag}$. It induces defence responses in plant cells in the absence of an actual threat, which improves secretion of phytohormones and increases tolerance for biotic and abiotic stress conditions. The response of the plants to the preparation, which appears just a few minutes after it penetrates the plant cells, includes the formation, perception and movement of signalling molecules and activation of defence genes. During this time the growth of the root system and above-ground parts of the plant becomes stronger (Gorczyca and Kasprowicz, 2011; Jankowski et al., 2013, Kocira et al., 2015; Stępień et al., 2016).

Various strains of useful bacteria, including Bacillus subtilis, have found application in agriculture. The action of biostimulants based on this species of bacteria involves reducing the number of pathogens within reach of the plants by competing with them for space and nutrient substances. These bacteria reduce the negative effect of pathogens, enhance the plants' resistance to disease, and create better phytosanitary conditions for the plants, thereby limiting the use of fungicides, increasing soil fertility, and promoting the decay of plant and root residues in the soil. Moreover, they secrete a variety of compounds into the soil, such as antibiotics, phytohormones, mucus and proteins, which stimulate plant growth and development (Stein, 2005; Canbolat et al., 2006). They also produce siderophores, which take part in transformations of iron compounds in the soil (making them available to the plants) (Jungwook et al., 2009).

Increasingly common are biostimulants based on humic acids, which improve the physical properties and sorption capacity of the soil and also reduce nutrient retention and leaching. Humic acids also have a beneficial effect on plants: they increase oxygen absorption in the cells, stimulate root system development, increase cell membrane permeability, stimulate rooting by inducing the growth of roots, especially root hairs, activate enzymes, mitigate stress during foliar pesticide spraying, stimulate photosynthesis by increasing chlorophyll content, and improve the effectiveness of mineral fertilizers. Following application of humic acids is also observed the improvement of the biological life of the soil (Lipşa et al., 2012; Poloskin et al., 2013; Shalaby and ElRamady, 2014; Galeş and Jităreanu, 2015).

The studies cited above described the effect of biostimulants on plant growth and development, soil conditions, and plant health. The literature contains few reports on the effect of these biostimulants on the chemical composition of garlic plants.

The objective of the study was to evaluate the effect of three biostimulants: first based on nano-concentrations of 7 microelements in the form of sulfates, second contains bacteria Bacillus subtilis and the third based on humic acids. The influence of those preparations on the chemical composition and level of bioactive compounds in the leaves, stems and bulbs of garlic was examined.

\section{Materials and Methods}

\section{Course of the experiment}

The experiment was conducted in three consecutive growing seasons in 2012-2015 on an experimental plot of the Department of Vegetable and Medicinal Plants in Mydlniki, Krakow, Poland. The study was conducted on the winter garlic cultivar 'Ornak'. The propagating material was treated in aqueous solutions of the biostimulants in the concentrations mentioned below. The control material was soaked in water. The garlic was planted at the end of October the year before cultivation, i.e. on 24 October 2012, 25 October 2013 and 3 November 2014, at $30 \times 10$ $\mathrm{cm}$ spacing. During the growing season the plants were sprayed three times with the biostimulants at monthly intervals (beginning of April, beginning of May, and beginning of June). The control plants were sprayed with water. The experiment was set up in a randomized block design in four replications with 60 plants each. No plant protection was used during plant growth because there were no signs of disease but only isolated appearances of pests. All agrotechnical practices applied during plant growth in the field were in accordance with recommendations for garlic.

Meteorological conditions during the experiment in relation to the period 1981-2010

Data on weather conditions in the period from October 2012 to July 2015 were taken from the nearby Meteorological Station belonging to the Institute of Meteorology and Water Management in Kraków-Balice. Average monthly air temperature $(t)$, sum of precipitation (P) and number of days with precipitation (NDP) in the research period were compared to the long-term averages from 1981-2010 (Table 1).

The overwintering period of garlic (December-March) was colder than average in the first year of the experiment, but warmer in subsequent years, while the spring and summer period (April-July) in the 2012/2013 and $2014 / 2015$ seasons was warmer than average, which in terms of the heat requirements of garlic was beneficial. In the spring/summer period of the 2013/2014 season, April and July were very warm, but May and June were cooler.

Precipitation conditions were most similar to the longterm averages in 2014/2015, in terms of both the precipitation sum and the number of days with 
precipitation. Precipitation in the $2012 / 2013$ was more frequent than average, but low. The 2013/2014 season was varied in terms of the amount and frequency of precipitation and did not correspond to the rainfall requirements of garlic. June (when the plants reach optimum size) was dry and July (when the bulbs should be drying out) was wet.

\section{Description of the biostimulants}

Stimulator 1 - it takes the form of an oligosaccharide granule containing sulphates of iron, cobalt, aluminium, magnesium, manganese, nickel and silver at a concentration of $10^{-9} \mathrm{~mol}$. Granules are dissolved in water and applied in the form of a seed dressing or sprayed on plants. The used dose: 1 granule per $1 \mathrm{dm}^{3}$.

Stimulator 2 - consists of one strain of the bacterium Bacillus subtilis. To activate the bacteria the preparation is mixed with water a few hours before use and is applied in the form of a dressing and sprayed onto the soil and the plants in concentration $3 \%$.

Stimulator $\mathbf{3}$ - is the soil condition enhancer. It is a concentrate of humic and fulvic acids supplemented with macro- and microelements. It is mixed with water and applied in the form of a dressing, poured onto the soil, and sprayed on the soil and plants, in concentration $0.5 \%$.

\section{Preparation of the research material}

The garlic leaves and stems for analysis were harvested at the beginning of May and the bulbs were collected in midJuly. The fresh samples were freeze-dried with a Martin Christ Alpha 1-4 freeze dryer (Germany).

The chemical composition of the leaves, stems and bulbs was tested in two replications. A $5 \mathrm{~g}$ sample of freeze-dried material was collected and homogenized with $80 \mathrm{ml}$ of $70 \%$ methanol using a CAT homogenizer (type X 120, USA). The sample was shaken for 2 hours at room temperature using an Elpan 357 shaker (Poland). The resulting solution was centrifuged (MPW-340 centrifuge, Poland) and filtered. The resulting extracts were stored at $-22^{\circ} \mathrm{C}$.

\section{Laboratory analysis of the proximate chemical composition of the garlic}

Dry matter (\% FW) was determined by the oven-dry method. Prior to analysis of proximate composition and fibre content, the fresh material was freeze-dried in a Martin Christ Alpha 1-4 freeze dryer (Germany). Total proteins, crude fat, and ash were measured according to AOAC (2006) procedures (950.36, 935.38 and 930.05, respectively). The total carbohydrate level was calculated as the differences between dry mass and proteins, fat, and ash.

\section{Analysis of bioactive compounds in the garlic}

Total dietary fibre (g $\left.100 \mathrm{~g}^{-1} \mathrm{DM}\right)$ (991.43) was measured according to AOAC (2006) methods.

L-ascorbic acid (mg $100 \mathrm{~g}^{-1} \mathrm{FW}$ ) was determined according to Tillmans by titration of extracts with indophenol solution.

The total concentration of phenolic compounds ( $\mathrm{mg}$ chlorogenic acid $100 \mathrm{~g}^{-1} \mathrm{FW}$ ) was measured with FolinCiocalteu's reagent (Sigma St. Louis Missouri, USA). The level of total polyphenolic compounds in the extracts was determined by spectrometry according to the FolinCiocalteu procedure.

Antioxidant activity ( $\mu \mathrm{mol}$ TEAC $1 \mathrm{~g}^{-1}$ FW) was measured by determining the ability to quench $\mathrm{ABTS}^{\bullet+}(2$, 2'-azinobis-(3-ethylbenzothiazoline-6-sulfonic acid) free radical. Values obtained for each sample were compared to the concentration-response curve of a standard Trolox solution.

\section{Statistical procedures}

The results were statistically analysed using analysis of variance for double classification by HSD Tukey's test, with $\mathrm{p}=0.05$ in Statistica $10(\mathrm{p}=0.05)$.

Table 1. Mean monthly air temperature $(\mathrm{t})$, sum of precipitation $(\mathrm{P})$ and number of days with precipitation (NDP) during the experiment in relation to the long-term averages

\begin{tabular}{ccccccccccccc}
\hline \multirow{2}{*}{ Years } & \multirow{2}{*}{ Parameter } & \multicolumn{1}{c}{ Month } & \multicolumn{1}{c}{ Jun } \\
\cline { 3 - 11 } & & Oct & Nov & Dec & Jan & Feb & Mar & Apr & May & Jun \\
\hline \multirow{3}{*}{$1981-2010$} & $\mathrm{t}\left[{ }^{\circ} \mathrm{C}\right]$ & 8.7 & 3.1 & -0.9 & -2.1 & -0.8 & 3.1 & 8.7 & 14.0 & 16.8 & 18.8 \\
& $\mathrm{P}[\mathrm{mm}]$ & 43 & 41 & 39 & 37 & 30 & 40 & 46 & 81 & 87 & 88 \\
& $\mathrm{NDP}$ & 10 & 12 & 13 & 12 & 11 & 11 & 10 & 12 & 13 & 13 \\
\hline \multirow{3}{*}{$2012 / 13$} & $\mathrm{t}\left[{ }^{\circ} \mathrm{C}\right]$ & 8.5 & $5.0 \uparrow$ & $-2.8 \downarrow$ & $-2.4 \downarrow$ & $-0.5 \downarrow$ & $-0.9 \downarrow$ & $8.9 \uparrow$ & 14.2 & $17.5 \uparrow$ & $19.5 \uparrow$ \\
& $\mathrm{P}[\mathrm{mm}]$ & $96 \uparrow$ & $22 \downarrow$ & $27 \downarrow$ & $62 \uparrow$ & $22 \downarrow$ & 32 & $20 \downarrow$ & 99 & $213 \uparrow$ & $27 \downarrow$ \\
& $\mathrm{NDP}$ & $16 \uparrow$ & 11 & $17 \uparrow$ & $22 \uparrow$ & $16 \uparrow$ & $15 \uparrow$ & 11 & $16 \uparrow$ & $17 \uparrow$ & $8 \downarrow$ \\
\hline \multirow{3}{*}{$2013 / 14$} & $\mathrm{t}\left[{ }^{\circ} \mathrm{C}\right]$ & $10.0 \uparrow$ & $4.9 \uparrow$ & $1.2 \uparrow$ & $-1.1 \uparrow$ & $2.2 \uparrow$ & $6.5 \uparrow$ & $10.2 \uparrow$ & 13.9 & $16.2 \downarrow$ & $20.2 \uparrow$ \\
& $\mathrm{P}[\mathrm{mm}]$ & $14 \downarrow$ & $71 \uparrow$ & $22 \downarrow$ & 38 & $17 \downarrow$ & 33 & 43 & $108 \uparrow$ & $43 \downarrow$ & $100 \uparrow$ \\
& $\mathrm{NDP}$ & $4 \downarrow$ & $17 \uparrow$ & $10 \downarrow$ & $17 \uparrow$ & 9 & 10 & $17 \uparrow$ & $15 \uparrow$ & 11 & 12 \\
\hline \multirow{2}{*}{$2014 / 15$} & $\mathrm{t}\left[{ }^{\circ} \mathrm{C}\right]$ & $9.6 \uparrow$ & $5.9 \uparrow$ & $1.3 \uparrow$ & $1.1 \uparrow$ & $0.5 \uparrow$ & $4.6 \uparrow$ & 8.7 & $13.0 \downarrow$ & $17.5 \uparrow$ & $20.6 \uparrow$ \\
& $\mathrm{P}[\mathrm{mm}]$ & $34 \downarrow$ & 38 & $23 \downarrow$ & $49 \uparrow$ & $26 \downarrow$ & 36 & 42 & $104 \uparrow$ & $36 \downarrow$ & $42 \downarrow$ \\
& $\mathrm{NDP}$ & 9 & 10 & 11 & $16 \uparrow$ & $8 \downarrow$ & $15 \uparrow$ & 9 & $16 \uparrow$ & $9 \downarrow$ & $9 \downarrow$ \\
\hline
\end{tabular}

Note: $\uparrow$-value higher than the long-term averages from 1981-2010: precipitation and number of days with precipitation by at least $25 \%$; temperature by at least $1{ }^{\circ} \mathrm{C}$ in October-April and $0.5^{\circ} \mathrm{C}$ in May-July. $\downarrow$ - value lower than the long-term averages from 1981-2010: precipitation and number of days with precipitation by at least 25\%; temperature by at least $1^{\circ} \mathrm{C}$ in October-April and $0.5^{\circ} \mathrm{C}$ in May-July 


\section{Results}

Chemical composition and content of bioactive compounds in garlic leaves, stems and bulbs

The level of dry matter and the content of individual bioactive compounds in the garlic depended significantly on the organ (Table 2). The garlic bulbs had the highest content of dry matter and total carbohydrates and the lowest fat content, while the leaves contained the most protein and ash. The stems had the lowest levels of protein, fat and ash, but proved to be a good source of sugars.

Among the organs tested the leaves had the highest content of bioactive compounds, i.e. dietary fibre, ascorbic acid, and polyphenols, and exhibited the highest antioxidant activity. The level of bioactive compounds was lowest in the bulbs.

Changes induced by the biostimulants in the proximate composition of individual garlic organs

The biostimulants tested were found to have a significant effect on the chemical composition of the garlic leaves, stems and bulbs, but the effect varied depending on the year of the study. The level of dry matter in the leaves and stems did not depend on the stimulator used (Table 3). In the bulbs, however, higher dry matter content was observed in the treatments where stimulators based on humic acids (stimulator 3) and bacterium Bacillus subtilis (stimulator 2) were used. The highest content of dry matter in the leaves was observed in 2015, in the stems in 2013 and 2014, and in the bulbs in 2013 and 2015.

The biostimulants tested were found to have a significant effect on the protein content of individual edible garlic organs (Table 4). The most protein was observed in leaves of the plants treated with stimulator 2 (based on Bacillus subtilis) and in the stems and bulbs from the stimulator 3 treatment (based on humic acids). Protein content in the leaves and stems was lowest in 2013, significantly higher in 2014, and the highest in 2015. Only in the bulbs were protein levels highest in 2014.

There was no influence of tested stimulators on fat content in leaves and stems of garlic (Table 5). The level of fat in bulbs increased in all objects where stimulators were used. Fat accumulation in the aerial parts (leaves and stems) was greatest in 2013 and in the bulbs there were no differences between years stated.

All applied stimulants reduced the sugar content in the garlic leaves as compared to the control (Table 6). In the stems and bulbs, the lowest sugar content was observed in plants treated with stimulator 3, based on humic acids. Sugar accumulation in the aerial parts (leaves and stems) was greatest in 2013 and in the bulbs in 2013 and 2015.

Higher ash content in the garlic leaves was observed in all treatments in which one of the biostimulants was used (Table 7).

Table 2. Comparison of proximate composition (per $100 \mathrm{~g}$ DM), bioactive compounds and antioxidant properties of various parts of garlic (mean for three years of research)

\begin{tabular}{|c|c|c|c|}
\hline Compounds & Leaves & Stems & Bulbs \\
\hline Dry matter \% & $13.31 \mathrm{a}$ & $24.02 \mathrm{~b}$ & $40.44 \mathrm{c}$ \\
\hline Ash (g) & $10.36 \mathrm{c}$ & $3.40 \mathrm{a}$ & $5.39 \mathrm{~b}$ \\
\hline Protein $(\mathrm{g})$ & $29.25 \mathrm{c}$ & $13.94 \mathrm{a}$ & $20.32 \mathrm{~b}$ \\
\hline Fat $(\mathrm{g})$ & $3.18 \mathrm{c}$ & $1.30 \mathrm{~b}$ & $0.97 \mathrm{a}$ \\
\hline Total carbohydrates (g) & $57.22 \mathrm{a}$ & $81.36 \mathrm{c}$ & $73.32 \mathrm{~b}$ \\
\hline 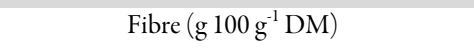 & $38.86 \mathrm{~b}$ & $25.44 \mathrm{a}$ & $26.82 \mathrm{a}$ \\
\hline Ascorbic acid (mg $\left.100 \mathrm{~g}^{-1} \mathrm{FW}\right)$ & $9.65 \mathrm{~b}$ & $6.67 \mathrm{a}$ & $6.48 \mathrm{a}$ \\
\hline Total polyphenols (mg CGA $100 \mathrm{~g}^{-1} \mathrm{FW}$ ) & $241.73 c$ & $144.95 \mathrm{~b}$ & $38.67 \mathrm{a}$ \\
\hline Antioxidant activity $\left(\mu \mathrm{mol}\right.$ TEAC $\left.1 \mathrm{~g}^{-1} \mathrm{FW}\right)$ & $25.91 \mathrm{c}$ & $10.53 \mathrm{~b}$ & $4.24 \mathrm{a}$ \\
\hline
\end{tabular}

Note: Values with the same letters within a row do not differ significantly at $\mathrm{p}=0.05$ (Tukey's HSD test)

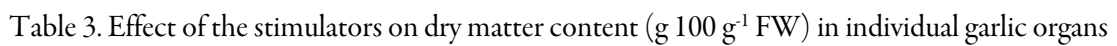

\begin{tabular}{|c|c|c|c|c|}
\hline Year & 2013 & 2014 & 2015 & Mean \\
\hline Stimulator & \multicolumn{4}{|c|}{ Leaves } \\
\hline Control & $12.96 \mathrm{a}$ & $13.13 \mathrm{a}$ & $13.23 \mathrm{a}$ & $13.11 \mathrm{~A}$ \\
\hline Stimulator $1^{*}$ & $13.77 \mathrm{a}$ & $12.32 \mathrm{a}$ & $14.26 \mathrm{a}$ & $13.45 \mathrm{~A}$ \\
\hline Stimulator 2 & $12.56 \mathrm{a}$ & $12.34 \mathrm{a}$ & $14.50 \mathrm{a}$ & $13.13 \mathrm{~A}$ \\
\hline Stimulator 3 & $12.23 \mathrm{a}$ & $13.07 \mathrm{a}$ & $15.31 \mathrm{a}$ & $13.54 \mathrm{~A}$ \\
\hline \multirow[t]{2}{*}{ Mean } & $12.88 \mathrm{~A}$ & $12.72 \mathrm{~A}$ & $14.33 \mathrm{~B}$ & \\
\hline & \multicolumn{4}{|c|}{ Stems } \\
\hline Control & $24.59 \mathrm{a}$ & $26.39 a$ & $20.85 a$ & $23.94 \mathrm{~A}$ \\
\hline Stimulator 1 & $32.10 \mathrm{a}$ & $22.60 \mathrm{a}$ & $21.41 \mathrm{a}$ & $25.37 \mathrm{~A}$ \\
\hline Stimulator 2 & $25.52 \mathrm{a}$ & $24.78 \mathrm{a}$ & $20.95 \mathrm{a}$ & $23.75 \mathrm{~A}$ \\
\hline Stimulator 3 & $23.93 \mathrm{a}$ & $27.22 \mathrm{a}$ & $17.89 \mathrm{a}$ & $23.01 \mathrm{~A}$ \\
\hline \multirow[t]{2}{*}{ Mean } & $26.54 \mathrm{~B}$ & $25.24 \mathrm{AB}$ & $20.27 \mathrm{~A}$ & \\
\hline & \multicolumn{4}{|c|}{ Bulbs } \\
\hline Control & $43.53 \mathrm{e}$ & $35.26 \mathrm{a}$ & $39.88 \mathrm{bc}$ & $39.55 \mathrm{~A}$ \\
\hline Stimulator 1 & $40.08 \mathrm{bcd}$ & $36.30 \mathrm{a}$ & $42.85 \mathrm{de}$ & $39.74 \mathrm{~A}$ \\
\hline Stimulator 2 & $42.96 \mathrm{e}$ & $37.71 \mathrm{ab}$ & $42.98 \mathrm{e}$ & $41.23 \mathrm{~B}$ \\
\hline Stimulator 3 & $42.84 \mathrm{de}$ & $39.11 \mathrm{bc}$ & 41.72 cde & $41.22 \mathrm{~B}$ \\
\hline Mean & $42.35 \mathrm{~B}$ & $37.10 \mathrm{~A}$ & $41.86 \mathrm{~B}$ & \\
\hline
\end{tabular}

Note: Analysis of significance of differences by Tukey's HSD test was performed separately for each
microelements, Stimulator 2 - is based on bacterium Bacillus subtilis, Stimulator 3 - is based on humic acids 
No effect of the biostimulants on ash level was observed in the stems. The bulbs from the stimulator 3 treatments had lower ash content than in the case of the other biostimulants. The highest content of minerals expressed as ash was noted in 2014 in all organs.

The analysis of weather patterns and deviations of selected meteorological elements (Table 1) from the norm in conjunction with the results shows that the weather conditions each year affected the content of dry matter, sugars and protein.

Mean for years and organs all used biostimulants increased the level of protein and ash but decreased the level of total carbohydrates (Fig. 1).

Table 4. Effect of the stimulators on protein content $\left(\mathrm{g} 100 \mathrm{~g}^{-1} \mathrm{DM}\right)$ in individual garlic organs

\begin{tabular}{|c|c|c|c|c|}
\hline Year & 2013 & 2014 & 2015 & Mean \\
\hline Stimulator & \multicolumn{4}{|c|}{ Leaves } \\
\hline Control & $19.35 \mathrm{ab}$ & $27.48 \mathrm{bc}$ & $35.31 \mathrm{cde}$ & $27.37 \mathrm{~A}$ \\
\hline Stimulator 1 & $19.69 \mathrm{ab}$ & $31.72 \mathrm{~cd}$ & $38.20 \mathrm{de}$ & $29.87 \mathrm{AB}$ \\
\hline Stimulator 2 & $18.28 \mathrm{a}$ & $37.51 \mathrm{de}$ & $41.54 \mathrm{e}$ & $32.44 \mathrm{~B}$ \\
\hline Stimulator 3 & $18.81 \mathrm{ab}$ & $30.51 \mathrm{~cd}$ & $32.59 \mathrm{~cd}$ & $27.31 \mathrm{~A}$ \\
\hline \multirow[t]{2}{*}{ Mean } & $19.03 \mathrm{~A}$ & $31.80 \mathrm{~B}$ & $36.91 \mathrm{C}$ & \\
\hline & \multicolumn{4}{|c|}{ Stems } \\
\hline Control & $6.97 \mathrm{a}$ & $11.70 \mathrm{ab}$ & $17.47 \mathrm{bcd}$ & $12.04 \mathrm{~A}$ \\
\hline Stimulator 1 & $7.32 \mathrm{a}$ & $12.43 a b c$ & $19.31 \mathrm{~cd}$ & $13.02 \mathrm{~A}$ \\
\hline Stimulator 2 & $7.47 a$ & $12.44 a b c$ & $22.72 \mathrm{~d}$ & $14.21 \mathrm{AB}$ \\
\hline Stimulator 3 & $7.90 \mathrm{a}$ & $11.69 \mathrm{ab}$ & $29.83 \mathrm{e}$ & $16.47 \mathrm{~B}$ \\
\hline \multirow[t]{2}{*}{ Mean } & $7.42 \mathrm{~A}$ & $12.07 \mathrm{~B}$ & $22.33 \mathrm{C}$ & \\
\hline & \multicolumn{4}{|c|}{ Bulbs } \\
\hline Control & $16.46 \mathrm{ab}$ & $27.45 c$ & $16.21 \mathrm{a}$ & $20.05 \mathrm{~A}$ \\
\hline Stimulator 1 & $17.21 \mathrm{ab}$ & $25.57 \mathrm{c}$ & $16.42 \mathrm{ab}$ & $19.73 \mathrm{~A}$ \\
\hline Stimulator 2 & $16.93 \mathrm{ab}$ & $24.83 c$ & $18.91 \mathrm{~b}$ & $20.22 \mathrm{AB}$ \\
\hline Stimulator 3 & $18.96 \mathrm{~b}$ & $27.28 \mathrm{c}$ & $17.60 \mathrm{ab}$ & $21.28 \mathrm{~B}$ \\
\hline Mean & $17.39 \mathrm{~A}$ & $26.29 \mathrm{~B}$ & $17.29 \mathrm{~A}$ & \\
\hline
\end{tabular}

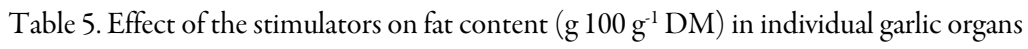

\begin{tabular}{|c|c|c|c|c|}
\hline Year & 2013 & 2014 & 2015 & Mean \\
\hline Stimulator & \multicolumn{4}{|c|}{ Leaves* $^{*}$} \\
\hline Control & $4.43 \mathrm{bc}$ & $2.65 \mathrm{ab}$ & $1.58 \mathrm{a}$ & $2.89 \mathrm{~A}$ \\
\hline Stimulator 1 & $4.34 \mathrm{bc}$ & $3.58 \mathrm{abc}$ & $2.29 a$ & $3.40 \mathrm{~A}$ \\
\hline Stimulator 2 & $5.50 \mathrm{c}$ & $2.56 \mathrm{ab}$ & $1.58 \mathrm{a}$ & $3.21 \mathrm{~A}$ \\
\hline Stimulator 3 & $4.50 \mathrm{bc}$ & $2.93 \mathrm{ab}$ & $2.19 a$ & $3.21 \mathrm{~A}$ \\
\hline \multirow[t]{2}{*}{ Mean } & $4.69 \mathrm{C}$ & $2.93 \mathrm{~B}$ & $1.91 \mathrm{~A}$ & \\
\hline & \multicolumn{4}{|c|}{ Stems } \\
\hline Control & $2.61 \mathrm{~b}$ & $0.81 \mathrm{a}$ & $0.76 a$ & $1.40 \mathrm{~A}$ \\
\hline Stimulator 1 & $1.16 \mathrm{ab}$ & $0.85 a$ & $1.40 \mathrm{ab}$ & $1.13 \mathrm{~A}$ \\
\hline Stimulator 2 & $1.84 \mathrm{ab}$ & $1.28 \mathrm{ab}$ & $0.95 \mathrm{a}$ & $1.36 \mathrm{~A}$ \\
\hline Stimulator 3 & $1.35 \mathrm{ab}$ & $1.20 \mathrm{ab}$ & $1.35 \mathrm{ab}$ & $1.30 \mathrm{~A}$ \\
\hline \multirow[t]{2}{*}{ Mean } & $1.74 \mathrm{~B}$ & $1.03 \mathrm{~A}$ & $1.11 \mathrm{~A}$ & \\
\hline & \multicolumn{4}{|c|}{ Bulbs } \\
\hline Control & $1.06 \mathrm{de}$ & $0.76 b c$ & $0.77 \mathrm{bc}$ & $0.86 \mathrm{~A}$ \\
\hline Stimulator 1 & $1.17 \mathrm{de}$ & $0.56 \mathrm{ab}$ & $1.27 \mathrm{de}$ & $1.00 \mathrm{~B}$ \\
\hline Stimulator 2 & $0.36 a$ & $1.32 \mathrm{e}$ & $1.03 \mathrm{~cd}$ & $0.93 \mathrm{AB}$ \\
\hline Stimulator 3 & $1.20 \mathrm{de}$ & $1.16 \mathrm{de}$ & $1.02 \mathrm{~cd}$ & $1.13 \mathrm{C}$ \\
\hline Mean & $0.95 \mathrm{~A}$ & $0.95 \mathrm{~A}$ & $1.02 \mathrm{~A}$ & \\
\hline
\end{tabular}




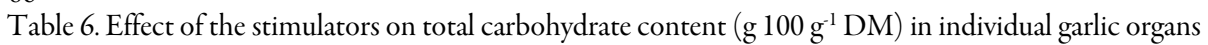

\begin{tabular}{|c|c|c|c|c|}
\hline Year & 2013 & 2014 & 2015 & Mean \\
\hline Stimulator & \multicolumn{4}{|c|}{ Leaves } \\
\hline Control & $64.45 \mathrm{e}$ & $57.80 \mathrm{cde}$ & $60.72 \mathrm{de}$ & $61.00 \mathrm{C}$ \\
\hline Stimulator 1 & $64.91 \mathrm{e}$ & $47.41 \mathrm{ab}$ & 55.80 bcde & $56.04 \mathrm{AB}$ \\
\hline Stimulator 2 & $64.60 \mathrm{e}$ & $42.27 \mathrm{a}$ & $52.25 \mathrm{abcd}$ & $53.04 \mathrm{~A}$ \\
\hline Stimulator 3 & $63.35 \mathrm{e}$ & $49.95 \mathrm{abc}$ & $63.06 \mathrm{e}$ & $58.79 \mathrm{BC}$ \\
\hline \multirow[t]{2}{*}{ Mean } & $64.34 \mathrm{C}$ & $49.36 \mathrm{~A}$ & $57.96 \mathrm{~B}$ & \\
\hline & \multicolumn{4}{|c|}{ Stems } \\
\hline Control & $87.36 \mathrm{~d}$ & $82.39 \mathrm{~cd}$ & $80.90 \mathrm{~cd}$ & $83.55 \mathrm{~B}$ \\
\hline Stimulator 1 & $88.59 \mathrm{~d}$ & $81.91 \mathrm{~cd}$ & $76.45 b c$ & $82.32 \mathrm{~B}$ \\
\hline Stimulator 2 & $87.47 \mathrm{~d}$ & $82.04 \mathrm{~cd}$ & $72.95 \mathrm{ab}$ & $80.82 \mathrm{AB}$ \\
\hline Stimulator 3 & $87.57 \mathrm{~d}$ & $82.88 \mathrm{~cd}$ & $65.83 \mathrm{a}$ & $78.76 \mathrm{~A}$ \\
\hline \multirow[t]{2}{*}{ Mean } & $87.75 \mathrm{C}$ & $82.31 \mathrm{~B}$ & $75.03 \mathrm{~A}$ & \\
\hline & \multicolumn{4}{|c|}{ Bulbs } \\
\hline Control & $78.97 \mathrm{de}$ & $62.44 \mathrm{a}$ & $79.99 \mathrm{e}$ & $73.80 \mathrm{~B}$ \\
\hline Stimulator 1 & 78.19 cde & $65.33 \mathrm{~b}$ & 77.52 cde & $73.68 \mathrm{AB}$ \\
\hline Stimulator 2 & 79.16 de & $65.03 \mathrm{ab}$ & $75.61 \mathrm{c}$ & $73.27 \mathrm{AB}$ \\
\hline Stimulator 3 & $76.49 \mathrm{~cd}$ & $63.24 \mathrm{ab}$ & 77.86 cde & $72.53 \mathrm{~A}$ \\
\hline Mean & $78.20 \mathrm{~B}$ & $64.01 \mathrm{~A}$ & $77.75 \mathrm{~B}$ & \\
\hline
\end{tabular}

Table 7. Effect of the stimulators on ash content $\left(\mathrm{g} 100 \mathrm{~g}^{-1} \mathrm{DM}\right)$ in individual garlic organs

\begin{tabular}{|c|c|c|c|c|}
\hline Year & 2013 & 2014 & 2015 & Mean \\
\hline Stimulator & \multicolumn{4}{|c|}{ Leaves* $^{*}$} \\
\hline Control & $11.72 \mathrm{c}$ & $12.10 \mathrm{c}$ & $2.39 \mathrm{ab}$ & $8.74 \mathrm{~A}$ \\
\hline Stimulator 1 & $11.06 \mathrm{c}$ & $17.29 \mathrm{~d}$ & $3.71 \mathrm{ab}$ & $10.69 \mathrm{~B}$ \\
\hline Stimulator 2 & $11.63 \mathrm{c}$ & $17.65 \mathrm{~d}$ & $4.64 \mathrm{~b}$ & $11.31 \mathrm{~B}$ \\
\hline Stimulator 3 & $13.33 \mathrm{c}$ & $16.61 \mathrm{~d}$ & $2.15 \mathrm{a}$ & $10.70 \mathrm{~B}$ \\
\hline \multirow[t]{2}{*}{ Mean } & $11.94 \mathrm{~B}$ & $15.91 \mathrm{C}$ & $3.22 \mathrm{~A}$ & \\
\hline & \multicolumn{4}{|c|}{ Stems } \\
\hline Control & $3.05 \mathrm{~b}$ & $5.10 \mathrm{~d}$ & $0.86 \mathrm{a}$ & $3.00 \mathrm{~A}$ \\
\hline Stimulator 1 & $2.92 \mathrm{~b}$ & $4.80 \mathrm{~cd}$ & $2.84 \mathrm{~b}$ & $3.52 \mathrm{~A}$ \\
\hline Stimulator 2 & $3.22 b c$ & $4.24 \mathrm{bcd}$ & $3.38 \mathrm{bcd}$ & $3.61 \mathrm{~A}$ \\
\hline Stimulator 3 & $3.08 \mathrm{bc}$ & $4.22 \mathrm{bcd}$ & $3.00 \mathrm{~b}$ & $3.47 \mathrm{~A}$ \\
\hline \multirow[t]{2}{*}{ Mean } & $3.10 \mathrm{~A}$ & $4.59 \mathrm{~B}$ & $2.52 \mathrm{~A}$ & \\
\hline & \multicolumn{4}{|c|}{ Bulbs } \\
\hline Control & $3.52 \mathrm{a}$ & $9.32 \mathrm{~d}$ & $3.02 \mathrm{a}$ & $5.29 \mathrm{AB}$ \\
\hline Stimulator 1 & $3.43 \mathrm{a}$ & $8.54 \mathrm{c}$ & $4.79 \mathrm{~b}$ & $5.59 \mathrm{~B}$ \\
\hline Stimulator 2 & $3.55 \mathrm{a}$ & $8.82 \mathrm{~cd}$ & $4.44 \mathrm{~b}$ & $5.61 \mathrm{~B}$ \\
\hline Stimulator 3 & $3.34 \mathrm{a}$ & $8.32 \mathrm{c}$ & $3.52 \mathrm{a}$ & $5.06 \mathrm{~A}$ \\
\hline Mean & $3.46 \mathrm{~A}$ & $8.75 \mathrm{C}$ & $3.94 \mathrm{~B}$ & \\
\hline
\end{tabular}

Changes induced by the biostimulants on bioactive compounds in individual garlic organs

Vitamin C content increased in the aerial parts (leaves and stems) of the garlic plants treated with stimulator based on nano-concentrations of microelements (stimulator 1) (Table 8). In the bulbs, however, the biostimulants did not affect the level of this vitamin. The highest level of vitamin C in the leaves and stems of garlic was observed 2013, while its highest content in the bulbs was noted in 2015.

The biostimulants were not found to affect the content of fibre in the garlic leaves or bulbs (Table 9). In the stems, however, significantly higher fibre content was observed in the stimulator 3 (based on humic acids) treatment as compared to the stimulator 1 (based on nano- concentrations of microelements) treatment. The highest fibre content in the leaves was observed in 2013, in the stems in 2014, and in the bulbs in 2013 and 2014.

Stimulator based on Bacillus subtilis caused a significant increase in polyphenol content in the garlic leaves with respect to the control (Table 10). In the stems, a significant effect of the biostimulants on the level of polyphenols was found only when the means for all years of research were compared; the plants treated with stimulator 3 had higher content of polyphenols than those treated with stimulator 1 . The level of polyphenols in the bulbs was increased by all the biostimulants, but was most influenced by stimulators 1 and 2. The highest content of polyphenols in the leaves was found in 2013, in the stems in 2014 and in the bulbs in 2015. 
Among the organs tested, the biostimulants were found to affect antioxidant activity only in the leaves (Table 11). The lowest activity was found in the leaves of the control plants. All biostimulants had a positive effect on this parameter. The highest antioxidant activity was found in the leaves in 2013 and 2014 and in the stems and bulbs in 2014.
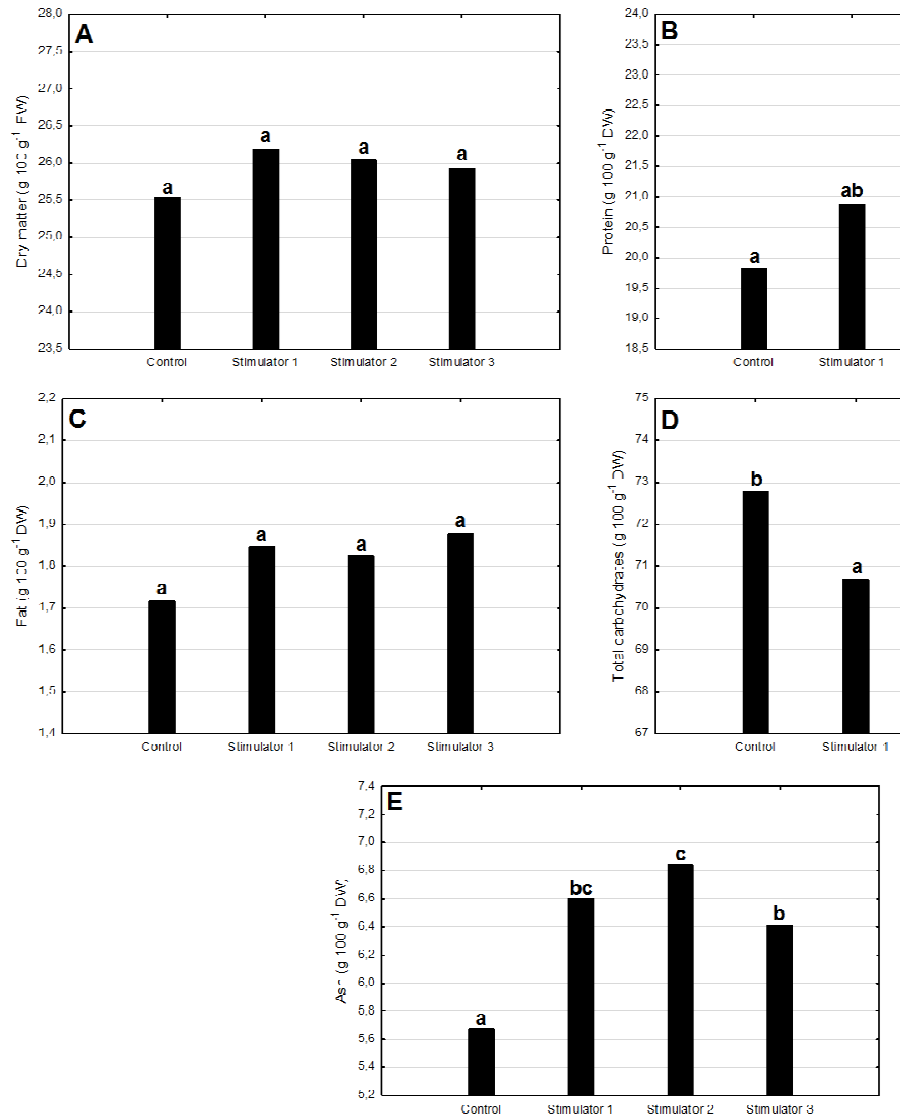

Fig. 1. The influence of preparations on chemical composition of garlic (mean for organs and years of investigation). Dry matter $(\mathrm{A})$, protein $(\mathrm{B})$, fat $(\mathrm{C})$, total carbohydrates $(\mathrm{D})$, ash $(\mathrm{E})$
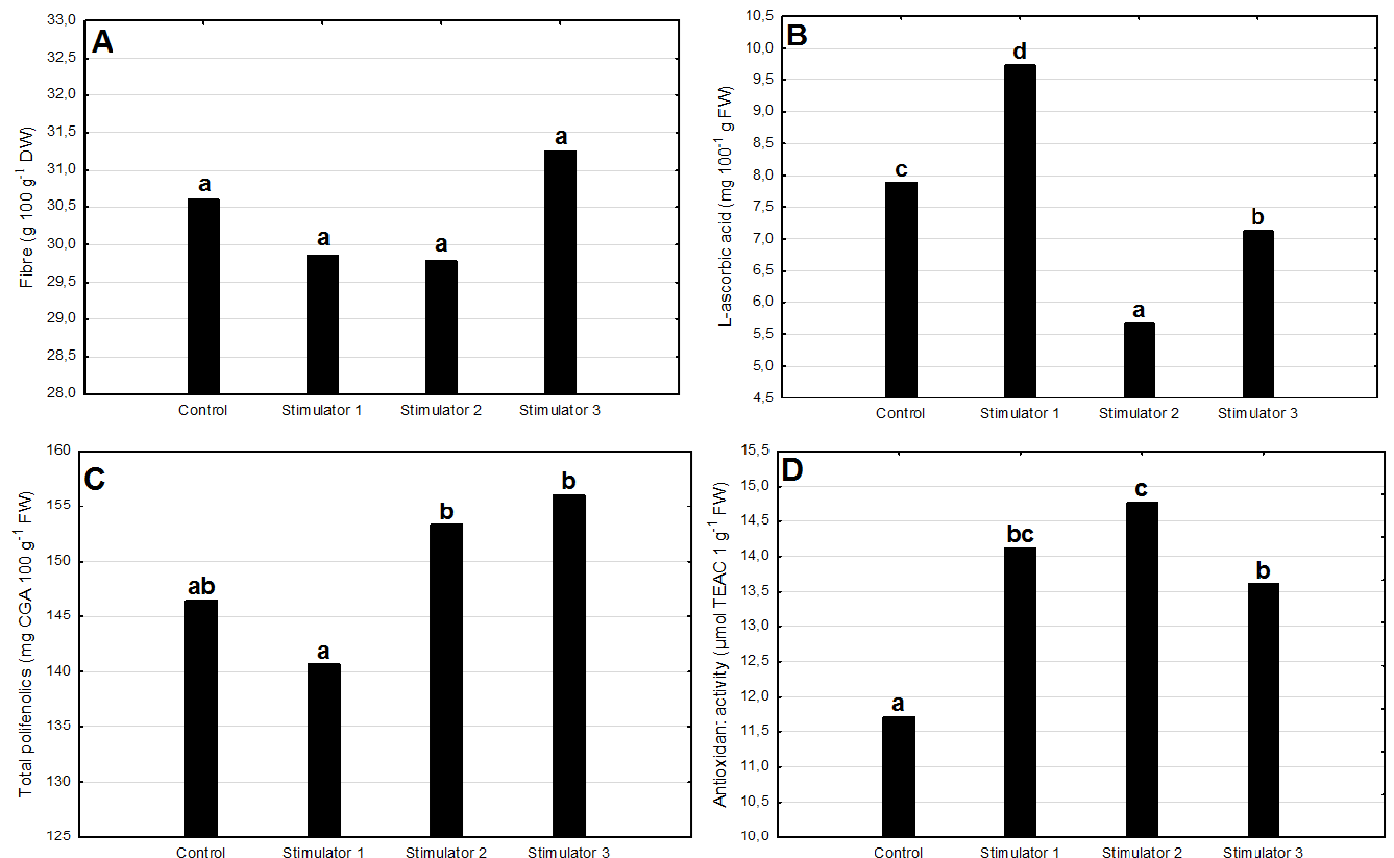

Fig. 2. The influence of preparations on bioactive compounds of garlic (mean for organs and years of investigation). Fibre (A), ascorbid acid (B), total polyphenols (C), antioxidant activity (D)

The level of bioactive compounds in the control and experimental treatments was varied in individual organs and may have been modified by weather conditions (Table 1).

Mean for years and organs all used biostimulants increased antioxidant activity but did not affected the level of fibre. Ascorbic acid and polyphenols content differed according to biostimulant (Fig. 2).
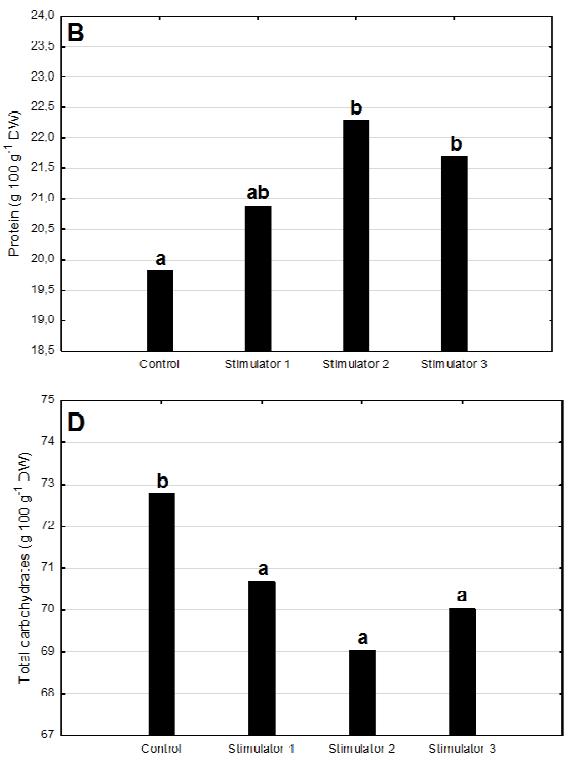
88

Table 8. Effect of the stimulators on ascorbic acid content $\left(\mathrm{mg} 100 \mathrm{~g}^{-1} \mathrm{FW}\right)$ in individual garlic organs

\begin{tabular}{|c|c|c|c|c|}
\hline Year & 2013 & 2014 & 2015 & Mean \\
\hline Stimulator & \multicolumn{4}{|c|}{ Leaves } \\
\hline Control & $15.06 \mathrm{~d}$ & $7.30 \mathrm{~b}$ & * & $11.18 \mathrm{C}$ \\
\hline Stimulator 1 & $18.91 \mathrm{e}$ & $7.71 \mathrm{bc}$ & * & $13.31 \mathrm{D}$ \\
\hline Stimulator 2 & $7.37 \mathrm{~b}$ & $3.45 \mathrm{a}$ & * & $5.41 \mathrm{~A}$ \\
\hline Stimulator 3 & $7.37 \mathrm{~b}$ & $10.10 \mathrm{c}$ & * & $8.74 \mathrm{~B}$ \\
\hline \multirow[t]{2}{*}{ Mean } & $12.18 \mathrm{~B}$ & $7.14 \mathrm{~A}$ & * & \\
\hline & \multicolumn{4}{|c|}{ Stems } \\
\hline Control & $6.41 \mathrm{~b}$ & $4.31 \mathrm{a}$ & * & $5.36 \mathrm{~A}$ \\
\hline Stimulator 1 & $13.46 \mathrm{~d}$ & $6.15 b$ & * & $9.81 \mathrm{~B}$ \\
\hline Stimulator 2 & $8.33 c$ & $3.56 \mathrm{a}$ & * & $5.95 \mathrm{~A}$ \\
\hline Stimulator 3 & $7.37 b c$ & $3.77 \mathrm{a}$ & * & $5.57 \mathrm{~A}$ \\
\hline \multirow[t]{2}{*}{ Mean } & $8.89 \mathrm{~B}$ & $4.45 \mathrm{~A}$ & * & \\
\hline & \multicolumn{4}{|c|}{ Bulbs } \\
\hline Control & $5.69 \mathrm{ab}$ & $8.53 \mathrm{~cd}$ & $9.09 \mathrm{~d}$ & $7.77 \mathrm{~A}$ \\
\hline Stimulator 1 & $6.44 \mathrm{abc}$ & $5.78 \mathrm{ab}$ & $8.48 \mathrm{~cd}$ & $6.90 \mathrm{~A}$ \\
\hline Stimulator 2 & $5.84 \mathrm{ab}$ & $5.43 \mathrm{a}$ & $9.39 \mathrm{~d}$ & $6.88 \mathrm{~A}$ \\
\hline Stimulator 3 & $6.14 \mathrm{abc}$ & $8.02 \mathrm{bcd}$ & $8.48 \mathrm{~cd}$ & $7.55 \mathrm{~A}$ \\
\hline Mean & $6.03 \mathrm{~A}$ & $6.94 \mathrm{~B}$ & $8.86 \mathrm{C}$ & \\
\hline
\end{tabular}

Note: See Table 3

${ }^{*}$ Data not included due to highly divergent results.

Table 9. Effect of the stimulators on fibre content $\left(\mathrm{g} 100 \mathrm{~g}^{-1} \mathrm{DM}\right)$ in individual garlic organs

\begin{tabular}{|c|c|c|c|c|}
\hline Year & 2013 & 2014 & 2015 & Mean \\
\hline Stimulator & \multicolumn{4}{|c|}{ Leaves } \\
\hline Control & $41.99 \mathrm{ab}$ & $37.53 \mathrm{a}$ & $36.95 \mathrm{a}$ & $38.82 \mathrm{~A}$ \\
\hline Stimulator 1 & $40.81 \mathrm{ab}$ & $37.78 \mathrm{ab}$ & $37.88 \mathrm{ab}$ & $38.82 \mathrm{~A}$ \\
\hline Stimulator 2 & $38.19 \mathrm{ab}$ & $36.32 \mathrm{a}$ & $39.11 \mathrm{ab}$ & $37.87 \mathrm{~A}$ \\
\hline Stimulator 3 & $44.37 \mathrm{~b}$ & $36.71 \mathrm{a}$ & $38.62 \mathrm{ab}$ & $39.90 \mathrm{~A}$ \\
\hline \multirow[t]{2}{*}{ Mean } & 41.34 B & $37.04 \mathrm{~A}$ & $38.14 \mathrm{~A}$ & \\
\hline & \multicolumn{4}{|c|}{ Stems } \\
\hline Control & $21.61 \mathrm{ab}$ & $28.66 \mathrm{bcd}$ & $23.85 \mathrm{abc}$ & $24.70 \mathrm{AB}$ \\
\hline Stimulator 1 & $18.62 \mathrm{ab}$ & $28.63 \mathrm{bcd}$ & $20.19 a b$ & $22.48 \mathrm{~A}$ \\
\hline Stimulator 2 & $26.96 \mathrm{abcd}$ & $35.45 \mathrm{~d}$ & $16.51 \mathrm{a}$ & $26.31 \mathrm{AB}$ \\
\hline Stimulator 3 & $26.57 \mathrm{abcd}$ & $34.05 \mathrm{~cd}$ & $24.18 \mathrm{abc}$ & $28.26 \mathrm{~B}$ \\
\hline \multirow[t]{2}{*}{ Mean } & $23.44 \mathrm{~A}$ & $31.70 \mathrm{~B}$ & $21.18 \mathrm{~A}$ & \\
\hline & \multicolumn{4}{|c|}{ Bulbs } \\
\hline Control & $33.77 \mathrm{~b}$ & $37.61 \mathrm{~b}$ & $13.42 \mathrm{a}$ & $28.27 \mathrm{~A}$ \\
\hline Stimulator 1 & $35.31 \mathrm{~b}$ & $35.41 \mathrm{~b}$ & $14.11 \mathrm{a}$ & $28.28 \mathrm{~A}$ \\
\hline Stimulator 2 & $28.47 \mathrm{~b}$ & $32.39 \mathrm{~b}$ & $14.62 \mathrm{a}$ & $25.16 \mathrm{~A}$ \\
\hline Stimulator 3 & $29.91 \mathrm{~b}$ & $34.40 \mathrm{~b}$ & $12.46 \mathrm{a}$ & $25.59 \mathrm{~A}$ \\
\hline Mean & $31.86 \mathrm{~B}$ & $34.95 \mathrm{~B}$ & $13.65 \mathrm{~A}$ & \\
\hline
\end{tabular}

Note: See Table 3

Table 10. Effect of the stimulators on total polyphenol content ( $\mathrm{g}$ chlorogenic acid $100 \mathrm{~g}^{-1} \mathrm{FW}$ ) in individual garlic organs

\begin{tabular}{|c|c|c|c|c|}
\hline Year & 2013 & 2014 & 2015 & Mean \\
\hline Stimulator & \multicolumn{4}{|c|}{ Leaves } \\
\hline Control & $276.95 \mathrm{~cd}$ & $144.62 \mathrm{a}$ & * & $224.02 \mathrm{~A}$ \\
\hline Stimulator 1 & $218.25 \mathrm{~b}$ & $249.10 \mathrm{bcd}$ & * & $230.59 \mathrm{~A}$ \\
\hline Stimulator 2 & $233.10 b c$ & $301.79 \mathrm{~d}$ & * & $260.58 \mathrm{~B}$ \\
\hline Stimulator 3 & $265.43 \mathrm{~cd}$ & $231.15 b c$ & * & $251.72 \mathrm{AB}$ \\
\hline \multirow[t]{2}{*}{ Mean } & 248.43 B & $231.67 \mathrm{~A}$ & $*$ & \\
\hline & \multicolumn{4}{|c|}{ Stems } \\
\hline Control & $120.95 \mathrm{a}$ & $193.27 \mathrm{~b}$ & * & $149.88 \mathrm{BC}$ \\
\hline Stimulator 1 & 109.88 a & $172.36 \mathrm{~b}$ & * & $134.87 \mathrm{~A}$ \\
\hline Stimulator 2 & 114.28 a & $177.20 \mathrm{~b}$ & * & $139.44 \mathrm{AB}$ \\
\hline Stimulator 3 & $126.28 \mathrm{a}$ & $199.61 \mathrm{~b}$ & * & $155.61 \mathrm{C}$ \\
\hline \multirow[t]{2}{*}{ Mean } & $117.85 \mathrm{~A}$ & $185.61 \mathrm{~B}$ & * & \\
\hline & \multicolumn{4}{|c|}{ Bulbs } \\
\hline Control & $28.97 \mathrm{a}$ & $62.02 \mathrm{~d}$ & $46.69 c$ & $45.89 \mathrm{~A}$ \\
\hline Stimulator 1 & $32.03 \mathrm{ab}$ & $39.12 \mathrm{bc}$ & $84.23 \mathrm{e}$ & $51.79 \mathrm{~B}$ \\
\hline Stimulator 2 & $28.96 \mathrm{a}$ & $44.13 \mathrm{c}$ & $80.44 \mathrm{e}$ & $51.17 \mathrm{~B}$ \\
\hline Stimulator 3 & $40.39 \mathrm{bc}$ & $33.73 \mathrm{ab}$ & $69.49 \mathrm{~d}$ & $47.87 \mathrm{AB}$ \\
\hline Mean & $32.59 \mathrm{~A}$ & $44.75 \mathrm{~B}$ & $70.21 \mathrm{C}$ & \\
\hline
\end{tabular}

${ }^{*}$ Data not included due to highly divergent results. 
Table 11. Effect of the stimulators on antioxidant activity $\left(\mu \mathrm{mol}\right.$ Trolox $\left.1 \mathrm{~g}^{-1} \mathrm{FW}\right)$ in individual garlic organs

\begin{tabular}{|c|c|c|c|c|}
\hline Year & 2013 & 2014 & 2015 & Mean \\
\hline Stimulator & \multicolumn{4}{|c|}{ Leaves } \\
\hline Control & $26.02 b c$ & $25.47 b c$ & $13,03 \mathrm{a}$ & $22.07 \mathrm{~A}$ \\
\hline Stimulator 1 & $36.43 \mathrm{~d}$ & $27.28 \mathrm{c}$ & $18.88 \mathrm{ab}$ & $27.49 \mathrm{BC}$ \\
\hline Stimulator 2 & $30.62 \mathrm{~d}$ & $34.57 \mathrm{~cd}$ & $22.23 b c$ & $29.92 \mathrm{C}$ \\
\hline Stimulator 3 & $30.31 \mathrm{~cd}$ & $28.53 \mathrm{~cd}$ & $17.95 \mathrm{ab}$ & 26.,01 B \\
\hline \multirow[t]{2}{*}{ Mean } & $30.84 \mathrm{~B}$ & $28.96 \mathrm{~B}$ & $18.02 \mathrm{~A}$ & \\
\hline & \multicolumn{4}{|c|}{ Stems } \\
\hline Control & $9.84 \mathrm{abc}$ & $13.25 \mathrm{~d}$ & $7.15 a$ & $10.54 \mathrm{~A}$ \\
\hline Stimulator 1 & $10.25 \mathrm{abc}$ & $11.62 \mathrm{bcd}$ & $9.10 \mathrm{abc}$ & $10.51 \mathrm{~A}$ \\
\hline Stimulator 2 & $9.17 \mathrm{abc}$ & $12.01 \mathrm{~cd}$ & $9.03 \mathrm{ab}$ & $10.35 \mathrm{~A}$ \\
\hline Stimulator 3 & $9.15 \mathrm{abc}$ & $13.95 \mathrm{~d}$ & $7.39 a$ & $10.71 \mathrm{~A}$ \\
\hline \multirow[t]{2}{*}{ Mean } & $9.61 \mathrm{~B}$ & $12.71 \mathrm{C}$ & $8.17 \mathrm{~A}$ & \\
\hline & \multicolumn{4}{|c|}{ Bulbs } \\
\hline Control & $2.37 a$ & $5.98 \mathrm{~cd}$ & $4.10 \mathrm{~b}$ & $4.41 \mathrm{~A}$ \\
\hline Stimulator 1 & $2.03 a$ & $6.46 \mathrm{~d}$ & $3.52 \mathrm{~b}$ & $4.36 \mathrm{~A}$ \\
\hline Stimulator 2 & $2.14 \mathrm{a}$ & $5.59 \mathrm{c}$ & $3.70 \mathrm{~b}$ & $4.01 \mathrm{~A}$ \\
\hline Stimulator 3 & $2.36 \mathrm{a}$ & $5.63 \mathrm{~cd}$ & $3.59 \mathrm{~b}$ & $4.11 \mathrm{~A}$ \\
\hline Mean & $2.23 \mathrm{~A}$ & $5.91 \mathrm{C}$ & $3.72 \mathrm{~B}$ & \\
\hline
\end{tabular}

\section{Discussion}

Despite numerous scientific reports concerning the chemical composition of garlic bulbs, which are the primary part of the plant used, information on the nutritional and medicinal value of its other organs can be found in only a few reports (Ejaz et al., 2003). The results of the experiment show that both the leaves and the stems can be an excellent alternative to garlic bulbs, particularly in early spring, when there is a lack of bulbs of good quality from storage and newly grown material is not yet available. The leaves contained the most protein, fats, and minerals expressed as ash, and were the richest in bioactive compounds. They had the highest content of fibre, vitamin $\mathrm{C}$, and polyphenols as well as the highest antioxidant activity of all the organs tested. Young garlic leaves can be eaten as early as March and can continue to be harvested until July. The stems can be harvested from hardneck garlic crops by the beginning of July. The stems could be used for food, as the results of this experiment have shown that their nutritional value is comparable to that of the bulbs, while the level of bioactive compounds, content of polyphenols and antioxidant activity are even higher.

Numerous authors emphasize that the use of growth and yield stimulators is aimed at accelerating plant development and improving crop quality. The results of our experiment showed that the use of the growth and development biostimulants affected the chemical composition of the garlic, but the effect varied in different weather conditions in the years of the research.

The study also showed substantial variation in the effect of each stimulator depending on organ tested. The greatest changes in proximate composition were observed in the bulbs, while the leaves and shoots showed only slight variation under the influence of the stimulators. The changes observed for bioactive compounds were much more pronounced. For vitamin $\mathrm{C}$, the effect of the stimulators was evident in all organs. Stimulator based on nanoconcentrations of microelements increased the level of vitamin C in the leaves (in 2013) and stems (in 2013 and 2014), while stimulator based on bacteria Bacillus subtilis reduced its content in the leaves (2013 and 2014) and increased it in the stems (2013). Many authors emphasize the significant effect of stimulator based on nanoconcentrations of microelements on crop quality. Jędrszczyk et al. (2016) demonstrated its positive influence on the content of lycopene and potassium in tomato fruits, and Kocira et al. (2015) reported a beneficial effect on the content of polyphenols and flavonoids in bean seeds. Stępien et al. (2016) showed that this stimulator increased the content of protein, gluten and certain minerals in the grain of common wheat and spelt.

A number of biostimulants based on Bacillus subtilis are used in horticulture; these improve soil conditions, which translates to better plant growth and development. Çakmakçi et al. (2007) reported a higher level of antioxidants in winter wheat and spinach following the application of Bacillus subtilis. Canbolat et al. (2006), in a study on barley, showed that these bacteria had a beneficial effect on dry matter in the roots and stems. The content of minerals $\mathrm{N}, \mathrm{P}, \mathrm{Mg}, \mathrm{Mn}, \mathrm{Zn}$ and $\mathrm{Cu}$ also increased with respect to the control.

The literature contains numerous reports on the effect of application of humic acids, the main component of stimulator 3 on the nutritional value of plants. Poloskin $e t$ al. (2013) showed that application of such stimulator caused an increase in the protein and fat content of soybeans and in the sugar content of sugar beets. Ertani et al. (2011), in a study on the effect of this stimulator on maize, showed an increase in chlorophyll, sugars (glucose and fructose) and protein. Galeş and Jităreanu (2015), in a study on soybean, demonstrated higher chlorophyll content in the leaves. Boček et al. (2009) used stimulator based on humic acids in combination with Synergin in strawberry crops and showed 
90

an increase in yield, vitamin C, and dry matter for individual cultivars. The results of the study presented in this paper show that the level of sugars was lower than in the control in the plants treated with stimulator 3 - in the leaves in 2014 and in the stems in 2015, while their ash content was higher. This stimulator contributed to a decrease in the amount of vitamin $C$ in the garlic leaves (in 2013 and 2014) and to an increase in polyphenol content in the leaves (in 2014).

The biostimulants were not found to affect the level of fibre in the leaves, stems or bulbs in any year of the study.

The influence of the biostimulants on the proximate composition of the organs was most evident in the bulbs. The level of bioactive constituents in the bulbs depended on the preparation used only in single cases, except for polyphenols. As compared to the control, all products tested had an adverse effect on polyphenols in 2014 and a favourable effect in 2015. This could be due to the protective function of the soil modifying the effect of the biostimulants in conjunction with weather conditions.

In conclusion, the biostimulants enhancing plant growth and development had varying effects on the chemical composition of individual edible organs, and this effect was dependent on meteorological conditions in a given year. Based on the results obtained in this work as well as studies by other authors (cited in the paper), continuation of research on the influence of these biostimulants on particular species of vegetable plants in various environmental and climatic conditions is fully justified.

\section{Conclusions}

The use of the growth and development biostimulants influenced the chemical composition of the garlic, but the effect was modified by the course of weather in different years of the research and also differ in individual edible organ. On average for years and organs all biostimulants increased the level of protein, minerals expressed as ash and enhanced antioxidant activity, whereas decreased the level of total carbohydrates. The most valuable edible organ proved to be the leaves of the garlic, which contained the most protein, fats, and minerals expressed as ash, were the richest source of fibre, vitamin $\mathrm{C}$ and polyphenols, and had the highest antioxidant activity of all the organs tested. The nutritional value of the stems was comparable to that of the bulbs, and the levels of polyphenols and antioxidant activity were even higher.

\section{Acknowledgements}

This work was supported by the Ministry of Science and Higher Education of Poland.

\section{References}

Ali MAM (2017). Effect of some Bio-stimulants on Growth, Yield and Bulb Quality of Garlic Grown in Newly Reclaimed Soil, New ValleyEgypt.Journal of Plant Production 8(12):1285-1294.

AOAC (2006). Official Methods of Analysis (18th ed). Gaithersburg, MD.

Bayan L, Koulivand PH, Gorji A (2014). Garlic: a review of potential therapeutic effects. Avicenna Journal of Phytomedicine 4(1):1-14.
Boček S, Salaš P, Sasková H, Patočková Š, MocričkováJ (2009). Preliminary results with using supplementary plant biostimulants Lignohumate B and Synergin in organic growing of strawberries. In: Proceedings, organic farming: response to economic and environmental challenges. Lednice naMoravě, Czech Republicpp 85-88.

Canbolat MY, Bilen S, Çakmakçi R, Şahin F, Ayidin A (2006). Effect of plant grow-promoting bacteria and soil compaction on barley seedling growth, nutrient uptake, soil properties and rhizosphere microflora. Biology and Fertility of Soils 42:350-357.

Çakmakçi R, Erat M, Ümmügülsüm E, Dönmez MF (2007). The influence of plant growth-promoting rhizobacteria on growth and enzyme activities in wheat and spinach plants. Journal of Plant Nutrition and Soil Science 170:288-295.

Ejaz S, Woong LC, Ejaz A (2003). Extract of garlic (Allium sativum) in cancer chemoprevention. Experimental Oncology 25:93-97.

Ertani A, Francioso O, Tugnoli V, Righi V, Nardi S (2011). Effect of commercial Lignosulfonate - Humate on Zea mays L. metabolism. Journal of Agricultural and Food Chemistry 59(22):11940-11948.

FAO (2014). Food and Agriculture Organization of the United Nations. Retrieved 2017 March 28 from http://www.fao.org/faostat/ en/\#data/QC.

Galeş DC, Jităreanu G (2015). The influence of humic fertilizer on morphological and physiological properties of soybean crop, in the conditions of the Moldavian plateau. Bulletin UASVM Agriculture 72(1):96-103.

GargN,Sekhon KS (2016). Earliness, yield and bulb parameters of hardneck garlic (Allium sativum L.) as influenced by leaf knotting and scape removal in north Indian plains. Journal of Spices and Aromatic Crops 25(2):182-186.

González RE, Sance MM, Soto VC, Galmarini CR (2012). Garlic scape, an alternative food with human health benefits. Acta Horticulturae 969:233-237.

Gorczyca A, Kasprowicz M (2011). Initial research on the effect of the NanoGro plant growth stimulator on Fusarium culmorum (W.G. Smith) Sacc. Ecological Chemistry and Engineering A 18(12):16251631.

Jankowski K, Deska J, Truba M, JankowskaJ (2013). Impact on Nano-Gro stimulator on the seeds germination and growth kinetics of seedlings of selected grass and legumes species. Environmental Protection and Natural Resources 24, 1(55):23-26.

Jędrszczyk E, Ambroszczyk AM (2016). The influence of Nano-Gro organic stimulator on the yielding and fruit quality of field tomato (Lycopersicon esculentum Mill.). Folia Horticulturae 28(1):87-94.

Jungwook Y, Kloepper JW, Choong-Min R (2009). Rhizosphere bacteria help plants tolerate abiotic stress. Trends in Plant Science 14(1):14.

Kallel F, Driss D, Chaari F, Belghith L, BouazizF, Ghorbel R, ChaabouniSE (2014). Garlic (Allium sativum L.) husk waste as a potential source of phenolic compounds: Influence of extracting solvents on its antimicrobial and antioxidant properties. Industrial Crops and Products 62:34-41.

Kamruzzaman M, Torita A, Sako Y, Al-Mamun M, Sano H(2011).Effects of feeding garlic stem and leaf silage on rates of plasma leucine turnover, whole body protein synthesis and degradation in sheep. Small Ruminant Research 99:37-43. 
Kocira A, Kocira S, Złotek U, Kornas R, Świeca M (2015). Effect of NanoGro preparation applications on yield components and antioxidant properties of common bean (Phaseolus vulgaris L). Fresenius Environmental Bulletin 24(11b):40344041.

Lipşa FD, Ulea E, Morari EC, Galeş D, Arsene IC (2012). Effect of Lignohumate (humic fertilizer) on soil microorganisms. Lucrări Ştiințifice Seria Agronomie 55(2):253-256.

Mikaili P, Maadirad S, Moloudizargari M, Aghajanshakeri S, Sarahroodi S (2013). Therapeutic uses and pharmacological properties of garlic, shallot and their biologically active compounds. Iranian Journal of Basic Medical Sciences 16(10):1031-1048.

Ourouadi S, Moumene H, Zaki N, Boulli A-A, Ouatmane A, Hasib A (2016). Garlic (Allium sativum): A source of multiple nutraceutical and functional components (review). Journal of Chemical, Biological and Physical Sciences 7(1):9-21.

Papu S, Jaivir S, SwetaS, Singh BR (2014). Medicinal values of garlic (Allium sativum L.) in human life: an overview. GreenerJournal of Agricultural Sciences 4(6):265-280.

Pelter GQ, Sorensen EJ, Van Denburgh RW, Hannan RM (2005). Effect of scape removal on garlic yield bulb in central Washington. Acta Horticulturae 688:323-326.

Poloskin RB, Gladkov OA, Osipova OA, Yakimenko OS (2013). Comparable evaluation of biological activity of new liquid and dry modifications of the humic product "Lignohumat Supere". In: Xu J, $\mathrm{Wu}$ J, $\mathrm{He} \mathrm{Y}$ (Eds). Functions of natural organic matter in changing environment.Springer,Dordrecht pp 1095-1099.

Rekowska E, Skupien K (2008). Estimation of yield and chemical composition of winter garlic grown for bunch-harvest. Journal of Central European Agriculture 9(4):711-714.
Rosen CJ, Tong CBS (2001). Yield, dry matter partitioning, and storage quality of hardneck garlic as affected by soil amendments and scape removal. HortScience 36(7):1235-1239.

Shafeek MR, Magda MH, Ali AH, Asmaa RM (2016). Effectiveness of foliar enforcement by amino acids and bio potassium fertilizer on growth, yield and bulb goodness of garlic plants under latterly reformed soil. Research Journal of Pharmaceutical, Biological and Chemical Sciences 7(5):836:844.

Shah NC (2014). Allium sativum (Garlic): The folk and modern uses - part I. TheScitech Journal 1(5):31-36.

Shalaby TA, El-Ramady H (2014). Effect of foliar application of biostimulants on growth, yield, components, and storability of garlic (Allium sativum L.). Australian Journal ofCrop Science 8(2):271-275.

Shiga Y, Tsutsui S, Mikami T (2015). Morphological characteristics and ancestry of Japanese garlic clones - An overview. Journal of Applied Horticulture 17(3):210-212.

Stein T (2005). Bacillus subtilis antibiotics: structures, syntheses and specific functions. Molecular Microbiology 56(4):845-857.

Stepień A, Wojtkowiak K, Orzech K, Wiktorkki A (2016). Nutritional and technological characteristics of common and spelt wheats are affected by mineral fertilizer and organic stimulator Nano-Gro. Acta Scientiarum Polonorum Series Agricultura 15(2):49-63.

Wu C, Wang M, Dong Y, Cheng Z, Meng H (2016). Effect of plant age and vernalization on bolting, plant growth and enzyme activity of garlic (Allium sativum L.).Scientia Horticulturae 201:295-305. 